\title{
Activin A and follistatin during the oestrous cycle and early pregnancy in ewes
}

\author{
Anne R O'Connell', Kenneth P McNatty ${ }^{2}$, Peter R Hurst ${ }^{3}$, Thomas E Spencer ${ }^{4, \ddagger}$, \\ Fuller W Bazer ${ }^{5}$, Karen L Reader ${ }^{1,+}$, Peter D Johnstone ${ }^{1}$, George H Davis ${ }^{1}$ \\ and Jennifer $L$ Juengel ${ }^{1}$
}

${ }^{1}$ Animal Reproduction, AgResearch Limited, Invermay Agricultural Centre, Puddle Alley Mosgiel, Mosgiel 9092, New Zealand

${ }^{2}$ School of Biological Sciences, Victoria University, Wellington 6021, New Zealand

${ }^{3}$ Department of Anatomy, School of Medical Sciences, University of Otago, Dunedin 9016, New Zealand ${ }^{4}$ Department of Animal Sciences, Washington State University, Pullman, Washington 99164-6353, USA

${ }^{5}$ Department of Animal Science, Center for Animal Biotechnology and Genomics, Texas A\&M University, College Station, Texas 77843-2471, USA

${ }^{\dagger} \mathrm{K}$ L Reader is now at Department of Anatomy, University of Otago, Dunedin 9016, New Zealand

${ }^{\ddagger} \mathrm{T}$ E Spencer is now at Department of Animal Sciences, University of Missouri, Columbia, MO 65211-5300, USA

\author{
Correspondence \\ should be addressed \\ to $\mathrm{J} L$ Juengel \\ Email \\ jenny.juengel@ \\ agresearch.co.nz
}

\begin{abstract}
The activin pathway has been postulated to be involved in regulation of multiple reproductive processes important for survival of the conceptus. These processes include luteinisation of the follicular cells and thus function of the corpus luteum, early embryo development and uterine function including implantation of the conceptus. Therefore, the aim of the current study was to determine whether the concentrations of activin $A$ and follistatin (FST), an activin-binding protein, differed between ewes with a lifetime history of enhanced or reduced embryonic survival (ES). The mRNAs encoding FST and activin A (inhibin beta A subunit; INHBA) were present in the uterus and abundant in the uterine luminal or glandular epithelia by day 18 of gestation. A peak of activin A was observed in the systemic circulation around the time of oestrus, and activin A concentrations were elevated in animals with reduced ES during the oestrous cycle and early gestation. Concentrations of activin $A$ in uterine fluid were approximately twofold greater on day 16 of gestation in ewes with reduced ES compared to those with enhanced ES. No consistent differences in FST were observed between these groups. Treatment of luteinising ovine granulosa cells with activin $A$ in vitro suppressed progesterone secretion providing evidence of a potential pathway whereby increased concentrations of activin A may decrease ES.
\end{abstract}

\author{
Key Words \\ - activin \\ - follistatin \\ - endometrium \\ - sheep \\ - early pregnancy
}

Journal of Endocrinology (2016) 228, 193-203

\section{Introduction}

In many species, including sheep, $>30 \%$ of fertilised ova fail to develop to term (Wilmut et al. 1985, Diskin \& Morris 2008). This reduces production efficiency in domestic animals; thus, reducing this loss is of considerable
(C) 2016 Society for Endocrinology Printed in Great Britain importance for livestock industries. In sheep that ovulate two or more ova, two types of loss can occur. Firstly, a certain proportion of ewes fail to become pregnant, often ovulating again after $\sim 17$ days, which is the normal 
oestrous cycle length for sheep (Quinlivan et al. 1966). The failure to become pregnant can be driven by multiple factors including infertility of the male. However, in many sheep, the ewe becomes pregnant, but one or more of the ova released fails to survive, resulting in partial failure of multiple ovulation (PFMO). In cases of PFMO, infertility of the male is excluded because at least one embryo is healthy. It is known that survival of an individual ovum is related to the number of ova ovulated, with ewes ovulating two ova that remain pregnant producing, on average, 1.7 lambs. Pregnant ewes that have ovulated three ova produce, on average, 2.2 lambs (Hanrahan 1982, Shorten et al. 2013). It is also known that individual outlier ewes for PFMO exist, with a lifetime history of having more or fewer lambs born than would be predicted by their observed ovulation rate (OR). This is consistent with these ewes having a natural difference in their ability to support a developing embryo. These differences potentially could be related to differing quality of the ova produced or a differing maternal environment for embryo development. Recently, we reported the identification of a group of genetically similar Coopworth ewes that have a lifetime pattern of high OR with either enhanced or reduced embryonic survival (ES) (O'Connell et al. 2013). Therefore, these animals provide a powerful and unique animal model to identify maternal pathways that are potentially important for survival of the embryo.

The activin pathway has been postulated to be involved in regulation of multiple reproductive processes including ovarian follicular development (Knight et al. 2012), luteinisation of the follicular cells (Myers et al. 2008, Kayani et al. 2009), early embryo development (Rajput et al. 2013) and uterine function during implantation of the conceptus (Singh et al. 2011). As a member of the transforming growth factor beta superfamily of growth factors, activin forms from the dimerisation of two $\beta$-subunits of inhibin (INHB), with different combinations forming functionally different isoforms (Knight 1996, Mellor et al. 2003). Follistatin (FST), a structurally unrelated protein, is known to bind activin to regulate its activity (Walton et al. 2012).

Given the potential of activin to affect ES at multiple levels, we hypothesised that activin, or its binding protein FST, may be differentially expressed between ewes with a lifetime history of reduced or enhanced ES. Therefore, to better understand the potential role of this pathway in regulation of ES, we determined the cellular localisation of FST and INHBA mRNA expression in the uterus in WT ewes during the late luteal phase of the oestrous cycle and early gestation (experiment 1). For ewes with a lifetime history of enhanced or reduced ES than that predicted by their OR, the concentration of FST and activin A in plasma during the oestrous cycle and early gestation were compared (experiment 2). The expression patterns of mRNAs in uterine tissue as well as the concentrations of FST and activin A in uterine fluid at the beginning of blastocyst implantation were also compared. Additionally, to better understand the mechanisms by which differing concentrations of activin A might lead to differing ES outcomes, we examined the effects of activin A on progesterone production from luteinising ovine granulosa cells, as increased progesterone concentrations during the early luteal phase have been linked to increased ES (Parr 1992, Robinson et al. 2008).

\section{Materials and methods}

\section{Animals}

All animal experiments were conducted following approval by the Animal Ethics Committee of the AgResearch Invermay Agricultural Centre in accordance with the Animals Protection Regulations (Codes of Ethical Conduct) of New Zealand. A schematic of the experiments undertaken is given in Fig. 1. The ewes (Ovis aries) were of either Romney or Coopworth (Romney cross) breeds and were sourced from the Invermay research farm. Multiparous ewes were treated with two intramuscular injections of $0.7 \mathrm{ml}$ Estrumate (active ingredient cloprostenol, a prostaglandin analogue, Intervet, Christchurch, New Zealand) 9 days apart to synchronise oestrus. The onset of oestrus (day 0 ) was detected by mating of the ewe by a vasectomised ram.

Experiment 1: to determine the expression pattern of FST and INHBA mRNAs in normal sheep, oestrous cycles of Romney ewes were synchronised as described above, and oestrous behaviour was monitored daily. A subset of the ewes detected in oestrus was immediately placed with a fertile ram to initiate pregnancy. The remaining ewes were retained for tissue collection during specified days of the oestrous cycle. Pregnancy was confirmed at the time of collection of the uterine tissue, and those animals that failed to become pregnant after exposure to the fertile ram were excluded from the study. After euthanasia using captive bolt and exsanguination, tissues were collected at day $14(n=4)$ or day $16(n=5)$ of the oestrous cycle or day $14(n=4)$, day $16(n=3)$ and day $18(n=4)$ of gestation (day $0=$ oestrus/mating).

For experiment 2, Coopworth ewes were selected based on their lifetime history of producing more lambs

Published by Bioscientifica Ltd 


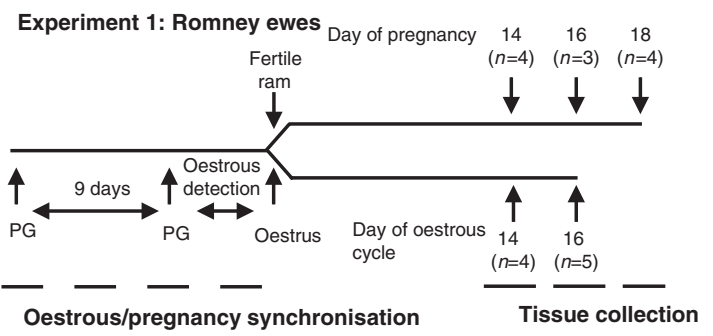

Experiment 2A: enhanced and reduced ES ewes oestrous cycle Enhance ES ewes $(n=5) \quad$ Blood sampling

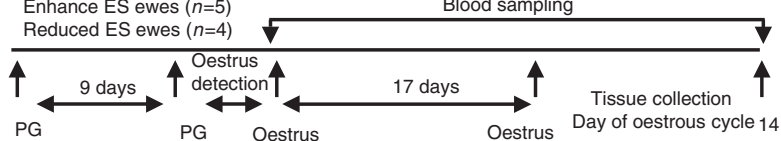

Experiment 2B: enhanced and reduced ES ewes pregnancy

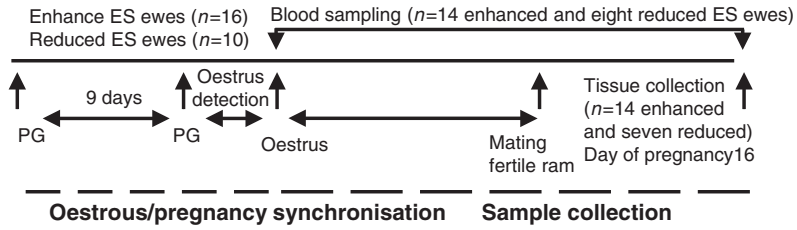

Figure 1

Schematic of timing of blood and tissue collections for experiments 1, 2A and $2 B$. In experiment 1 , oestrous cycles of Romney ewes were synchronised with two injections of a prostaglandin (PG) analogue given 9 days apart. Day of oestrous was detected using vasectomised rams. One group of ewes was immediately placed with a fertile ram when detected in oestrous to initiate pregnancy whereas the remainder of the ewes were left with the vasectomised ram. Tissues were collected on days specified. For experiments $2 \mathrm{~A}$ and $2 \mathrm{~B}$, oestrous cycles of ewes with enhanced or reduced ES were synchronised as for experiment 1 . Following oestrous synchronisation, the next natural oestrus was determined using a vasectomised (experiment 2A) or fertile (experiment 2B) rams. Blood samples and tissues were collected as specified.

(enhanced ES, $n=21$ ) or fewer lambs (reduced ES, $n=14$ ) than predicted by their OR using the equation developed by Hanrahan (1982):

Predicted litter size

$$
=0.015+(0.926 \times \mathrm{OR})-\left(0.0763 \times \mathrm{OR}^{2}\right)
$$

Selection of animals was as described by O'Connell et al. (2013). An ES score was calculated by subtracting the predicted litter size from the observed litter size using a minimum of three records per ewe. OR of the ewe was measured using laparoscopy (Kelly \& Allison 1976), and litter size was determined at lambing each year. The enhanced ES ewes had 0.32 more lambs than predicted whereas the reduced ES ewes had, on average, 0.53 fewer lambs than predicted. For experiment $2 \mathrm{~A}$, the ewes were exposed to a vasectomised ram $(n=5$ and $n=4$ for enhanced and reduced ES respectively) on the day of the second detected oestrus following synchronisation. For experiment $2 \mathrm{~B}$, ewes were bred by a fertile ram $(n=16$ and $n=10$ for enhanced and reduced ES respectively) on the day of the second detected oestrous following synchronisation. Ewes were then slaughtered on day 14 of the oestrous cycle or day 16 of gestation. Day 14 of the oestrous cycle was chosen, as this represents the start of the rise of prostaglandin secretion and thus the onset of luteal regression in the non-pregnant ewes (Shorten et al. 2010). Day 16 of gestation was chosen, as this represents the beginning of implantation of the conceptus (Spencer et al. 2004). Two of the 26 ewes mated with the fertile ram failed to become pregnant (from the reduced ES phenotype) and were excluded from the experiment. Collection of the tissues during the oestrous cycle and pregnancy occurred over two successive breeding seasons.

\section{Sampling}

For experiment 1 , only one uterine horn was flushed on days 16 and 18 of gestation to confirm pregnancy; thus, this uterine flush sample was not used for further analysis. For experiments $1,2 \mathrm{~A}$ and $2 \mathrm{~B}$, tissue samples from the mid-region of the uterine horn were fixed in $4 \% \mathrm{v} / \mathrm{v}$ paraformaldehyde and embedded in paraffin wax for histological sectioning. For experiments $2 \mathrm{~A}$ and $2 \mathrm{~B}$, daily blood samples were collected from ewes into heparinised tubes via venipuncture from the time of detection of first oestrus until tissue collection. For experiment 2B, following euthanasia of potentially pregnant ewes, uteri were flushed with sterile Tris-buffered saline $(10 \mathrm{ml}$ per horn, $\mathrm{pH}$ 7.2) with the recovered fluid from both horns pooled and frozen. Due to a calculation error, three ewes (two from the enhanced ES group and one in the reduced ES group) were collected later in pregnancy than intended; thus, the uterine fluid from these ewes was excluded from analysis.

\section{In situ hybridisation and microscopy}

CDNA for FST and INHBA was prepared in our laboratory, and the hybridisation procedure was as described previously (Tisdall et al. 1994, Logan et al. 2002). Briefly, 4-6 $\mu \mathrm{m}$ tissue sections were rehydrated and treated with proteinase K; slides were then acetylated to reduce nonspecific binding and dehydrated. Hybridisation solution, containing ${ }^{33} \mathrm{P}$-labelled RNA sense or anti-sense probe, was added to the slides which were then incubated at $50{ }^{\circ} \mathrm{C}$ overnight. Non-specific hybridisation was removed with RNase $A$ and stringent washes $(2 \times$ SSC, $50 \%$ formamide at

Published by Bioscientifica Ltd 
$65{ }^{\circ} \mathrm{C}$ and $0.2 \times$ SSC at $37{ }^{\circ} \mathrm{C}$ ). Slides were dehydrated and coated with LM1 emulsion (Amersham). After 3-4 weeks, slides were developed with D19 developer (Eastman Kodak, Rochester, NY, USA). Localisation of gene expression within a transverse section of the uterine tissue was evaluated qualitatively and not quantitatively. Uterine sections from three to five ewes were assessed for each time point and ES phenotype.

\section{Hormone assay}

A FST RIA (Phillips et al. 1996) and activin A ELISA assay (Knight et al. 1996) were performed on all plasma and uterine fluid samples. The samples from the ewes had been used in previous assays (O'Connell et al. 2013), and a limited amount of plasma remained for analysis with samples not being available from some ewes on some days. These values were treated as missing samples. Two animals from the enhanced ES had insufficient samples and were excluded from analysis. The minimum number of animals represented for any comparison was four. Assay detection limits and CV were $0.008 \mathrm{ng} / \mathrm{ml}$ and $<10 \%$ for the activin A ELISA and $2 \mathrm{ng} / \mathrm{ml}$ and $<10 \%$ for the FST RIA respectively.

Total protein in the uterine fluid was measured using a BCA Protein Assay Kit (Cat 23225, Pierce, Rockford, IL, USA) as per manufacturer's instructions.

\section{Quantitative RT-PCR}

From experiments $2 \mathrm{~A}$ and $2 \mathrm{~B}$, endometrial tissues from the mid-region of the uterus were used for quantitative RT-PCR. Tissue from a total of nine enhanced ES ewes (three collected during the oestrous cycle and six during pregnancy) and eight reduced ES ewes (four each collected during the oestrous cycle and pregnancy) were available for analysis. Total cellular RNA was isolated using Trizol (Life Technologies) according to the manufacture's recommendations. Further purification was undertaken using a QIAGEN RNeasy Mini Kit (Bio-Strategy Ltd) following the manufacture's protocol. Total cellular RNA (1000 ng) was DNase I treated prior to cDNA synthesis using Superscript III (Life Technologies) using the standard method. The sensitivity of the assay was optimised with a primer matrix approach for all genes using SYBR Green (Life Technologies). Absence of nonspecific products was assessed by dissociation curve analysis. Serial dilutions of a standard sample were used to calculate efficiency and range of each assay (Table 1). Identity of amplified products was confirmed by sequencing (Waikato DNA Sequencing Facility, Hamilton, New Zealand). Samples outside the upper range were considered below the sensitivity of the assay. The RPL19 mRNA was used as the reference to calculate $\triangle \mathrm{Ct}$. Average ( \pm s.E.M.) $R P L 19 \mathrm{Ct}$ for enhanced ES ewes $(20.37 \pm 0.24)$ was not different to the average $\mathrm{Ct}$ of reduced ES ewes (20.44 \pm $0.25 ; P=0.84)$. All samples were assayed at least in duplicate. A calibrator sample was assayed on every plate and was used to calculate the $\Delta \Delta \mathrm{Ct}$ for each sample. Samples that omitted the reverse transcriptase for cDNA synthesis and no template controls were included and gave the expected negative results for all assays.

\section{Culture of luteinising ovine granulosa cells}

Collection and culture of ovine granulosa cells were as previously described (Juengel et al. 2004). Briefly, ovaries were collected from the local abattoir and transported back to the laboratory. Follicles $\sim 1-2 \mathrm{~mm}$ in diameter were dissected from the ovaries and granulosa cells collected using a wire loop to scrape the walls of bisected follicles. A glass pipette was used to remove any oocytes or follicular debris. Cells (100 000/well per $250 \mu$ l total volume) were added to the culture plates in McCoys media (Sigma) with penicillin $(100 \mu / \mathrm{ml})$, streptomycin $(100 \mu \mathrm{g} / \mathrm{ml})$, $2 \mathrm{mM}$ GlutaMAX-1, androstenedione (30 $\mathrm{ng} / \mathrm{ml})$, insulin $(10 \mathrm{ng} / \mathrm{ml})$, apo-transferrin $(5 \mu \mathrm{g} / \mathrm{ml})$ and selenium ( $5 \mathrm{ng} / \mathrm{ml})$. Ovine FSH ( $3 \mathrm{ng} / \mathrm{ml}$, purified in our laboratory, $1.4 \times$ USDA-oFSH-19-SIAFP RP2) and IGF1 $(1 \mathrm{ng} / \mathrm{ml}$, Long-R3, GroPrep, Adelaide, SA, Australia) were also included.

Table 1 Primers for the quantitative PCR assays and assay characteristics

\begin{tabular}{|c|c|c|c|}
\hline \multirow[b]{2}{*}{ Gene } & \multirow[b]{2}{*}{$\begin{array}{l}\text { Product } \\
\text { size }\end{array}$} & \multicolumn{2}{|l|}{ Forward primer } \\
\hline & & Sequence & $\begin{array}{l}\text { Final } \\
\text { Conc } \\
(\mathrm{nM})\end{array}$ \\
\hline RPL19 & 116bp & GACGATACCGTGAATCTA & 200 \\
\hline$F S T$ & 105bp & CGTGTAAAGAAACGTGTG & 300 \\
\hline INHBA & $110 b p$ & GTACGTGGAGATAGAGGA & 300 \\
\hline
\end{tabular}

\begin{tabular}{ll}
\hline \multicolumn{2}{c}{ Reverse primer } \\
\hline \multicolumn{1}{c}{ Sequence } & $\begin{array}{l}\text { Final } \\
\text { Conc } \\
(\mathrm{nM})\end{array}$ \\
\cline { 1 - 2 } CAGCTTGTGGATATGTTC & 300 \\
GGTGATGTTAGAACAATCTG & 400 \\
CAGGAAGAGCCAGATTTC & 300 \\
\hline
\end{tabular}

http://joe.endocrinology-journals.org DOI: $10.1530 / J O E-15-0367$
(C) 2016 Society for Endocrinology Printed in Great Britain
Published by Bioscientifica Ltd. 
Cells were cultured in a $37{ }^{\circ} \mathrm{C}$ incubator with $5 \% \mathrm{CO}_{2}$ for 6 days. Media $(200 \mu \mathrm{l})$ was replaced every $48 \mathrm{~h}$. These culture conditions induce luteinisation of the granulosa cells, as progesterone concentrations in media from the last $48 \mathrm{~h}$ of culture were over fivefold greater than concentrations measured from media collected after the first $48 \mathrm{~h}$ of culture. A preliminary dose response of 1,10 and $100 \mathrm{ng} / \mathrm{ml}$ of rhActivin A (R\&D Systems, Pharmaco, Auckland, New Zealand) was undertaken with maximal inhibition of progesterone observed at $10 \mathrm{ng} / \mathrm{ml}$; therefore, the effects of rhActivin A at $10 \mathrm{ng} / \mathrm{ml}$ on progesterone and cell number (as assessed by DNA content) was measured in triplicate in five independent pools of granulosa cells. The media from the last $4800 \mathrm{~h}$ of culture was frozen at $-20{ }^{\circ} \mathrm{C}$ for determination of progesterone concentrations by RIA (Lun et al. 1998). The intra- and inter-assay coefficients of variation (CV) for three standard sample assayed at approximately 20,50 or $80 \%$ binding both averaged $<20 \%$ and no samples were below the sensitivity of the assay. At the end of culture, following collection of the media, unattached cells were removed by washing, and attached cells were lysed using incubation at $37{ }^{\circ} \mathrm{C}$ in distilled water for $1-2 \mathrm{~h}$. Cell lysates were frozen at $-70{ }^{\circ} \mathrm{C}$ until assayed for DNA content using a Hoechst 33258 based dye assay (Juengel et al. 2004). Intra- and inter-assay CV were $<10 \%$, and no samples were below the sensitivity of the assay.

\section{Statistical analyses}

Data for concentrations of activin A and FST in plasma were analysed following natural $\log$ transformation to normalise the data. Samples below the sensitivity of the assay were estimated using the fill-in method (Gleit 1985). Transformed values were analysed using REML fitting day of sample, group (enhanced or reduced ES) and pregnancy status, as well as two-way interactions, as main effects with animal fitted as a random variable. An autoregressive error structure was used to allow for heterogeneity between repeated measures. Concentrations of INHBA and FST mRNA were analysed using REML with pregnancy status and ES group as main effects with ewe as a random effect. No interaction was observed between pregnancy status and ES group; so, the data were combined for final analysis of ES group. Samples below the sensitivity of the assay (INHBA only) were estimated using the fill-in method (Gleit 1985). Concentrations of INHBA mRNA were transformed (natural $\log$ ) to normalise the data before analysis. Concentrations of activin A and FST in uterine fluid were analysed with ANOVA using total protein as a covariate. Following transformation (natural log), concentrations of progesterone and DNA following culture of granulosa cells with activin A or control media were compared using a paired $t$-test.

\section{Results}

\section{Expression of FST and INHBA mRNA in uterine tissues}

Expression of FST mRNA was observed in the luminal epithelium (LE) on days 14 and 16 of the oestrous cycle and during gestation (Fig. 2). On day 18 of gestation, expression was detected in the LE as well as trophectoderm cells of the conceptus (Fig. 2). No obvious differences in patterns of expression were seen between the enhanced and reduced ES groups on either day 14 of the oestrous cycle or day 16 of gestation (data not shown).

In uterine tissue collected from ewes during the oestrous cycle, INHBA mRNA was observed in the LE and stratum compactum stromal cells of the endometrium (Fig. 3). In uterine tissue from pregnant ewes, INHBA mRNA expression on day 14 was similar to that observed on day 14 of the oestrous cycle but with endometrial glands also containing INHBA mRNA. By day 18 of pregnancy, expression appeared to be limited to the uterine glands with no INHBA mRNA observed in other uterine cell types or the implanting conceptus. No differences in the patterns of expression were apparent between the ES groups (data not shown).

\section{Concentrations of FST and activin A in plasma}

As illustrated in Fig. 3, concentration of FST in plasma was affected by day of the oestrous cycle $(P<0.001)$, ES group $(P<0.05)$, pregnancy status $(P<0.01)$ and pregnancy status by ES group interaction $(P<0.001)$. Overall, concentrations of FST decreased $(P<0.05) \sim 10 \%$ between days -7 and -3 to reach a nadir on day -1 with day 0 being the day of oestrus onset. Following ovulation, increased $(P<0.05)$ concentrations of FST were detected by day 2 with peak values $\sim 20 \%$ above the nadir established by day 6 of the cycle. Overall, ewes with enhanced ES had 1.5-fold more FST than ewes with reduced ES. Ewes with enhanced ES had higher concentrations of FST during the oestrous cycle, but this was not apparent for pregnant ewes (Fig. 4).

Concentrations of activin A in plasma were affected by day of the oestrous cycle $(P<0.001)$, ES group $(P<0.001)$ and pregnancy status $(P<0.01)$, but no interactions were detected $(P>0.15)$. Overall, ewes with

Published by Bioscientifica Ltd 

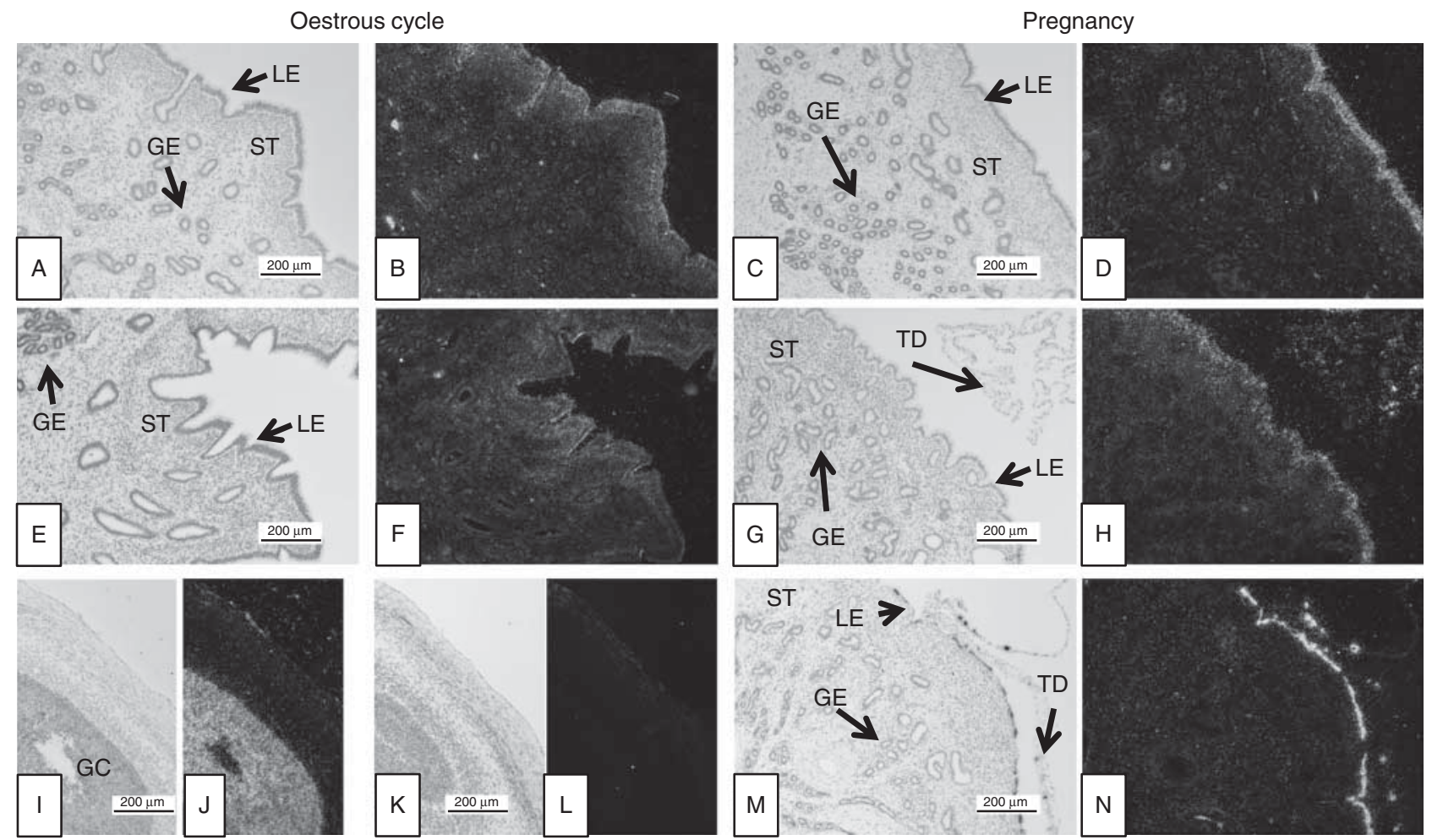

Figure 2

Bright field ( $A, C, E, G, I, K$, and $M$ ) or dark field images ( $B, D, F, H, J, L$, and $N$ ) of FST mRNA expression in uterine tissue collected from control Romney ewes on days $14(A, B, C$, and $D), 16(E, F, G$, and $H)$ or $18(M$ and $N)$ of the oestrous cycle (A, B, E, and F) or pregnancy (C, D, G, H, M, and N). Control ovarian tissue hybridised with either antisense (I, J; positive control) or sense (K, L; negative control) FST RNA probes. Some expression of FST mRNA in the LE was observed on days 14 and 16 of the oestrous cycle as well

enhanced ES had a modest 20\% decrease in concentrations of activin A compared to ewes with reduced ES (Fig. 5). Activin A concentrations in plasma were low, being at or just above the detection limits of the assay, on most days of the oestrous cycle or early gestation with the exception of the 2 days around oestrus, where a peak of activin A was detected (Fig. 5).

\section{Concentrations of FST and INHBA mRNA in endometrium of enhanced and reduced ES ewes}

Concentration of FST mRNA was similar between enhanced and reduced ES ewes (reduced ES ewes 88.2 \pm $24.0 \%$ of expression of enhanced ES ewes, $P=0.74)$. The concentration (geometric mean $95 \%$ confidence range) of INHBA mRNA from endometrium of reduced ES ewes was $167.0 \%$ (101.9-274.5\%) of that observed in enhanced ES, but this was not significantly different $(P=0.13)$. as gestation ( $A, B, C, D, E, F, G$, and $H$ ). No expression was observed in the glandular epithelia. On day 18 of gestation, expression in the LE as well as trophectoderm cells was detected. A signal was also detected in the endometrial stroma (ST) for all time periods ( $A, B, C, D, E, F, G, H, M$, and N). Expression was observed in the granulosa cells of the ovarian follicle when hybridised with the anti-sense RNA (I, J; positive control) but not with the sense RNA (K, L; negative control).

\section{Concentrations of FST and activin A in uterine flushes of enhanced and reduced ES ewes}

Concentrations of FST in uterine flushes collected on day 16 of gestation were not different between ewes with enhanced or reduced ES phenotypes (Table 2). In contrast, concentrations of activin A were twofold greater $(P<0.05)$ in uterine flushes collected from ewes with a reduced ES compared to those with an enhanced ES phenotype (Table 2).

\section{Effects of activin A on progesterone and DNA content in luteinising ovine granulosa cells}

Given that concentrations of activin A in sera, which were increased in reduced ES ewes compared to enhanced ES ewes, peaked during the time that the follicular cells would be undergoing luteinisation, we next examined the

Published by Bioscientifica Ltd 
Oestrous cycle
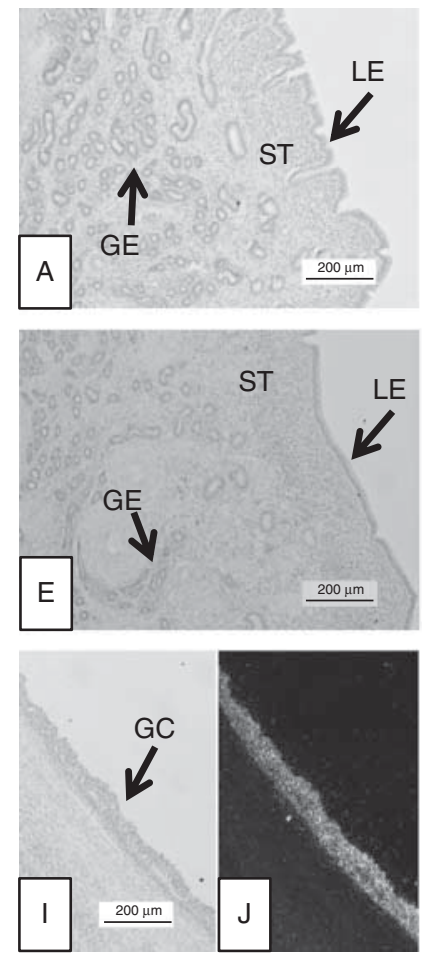
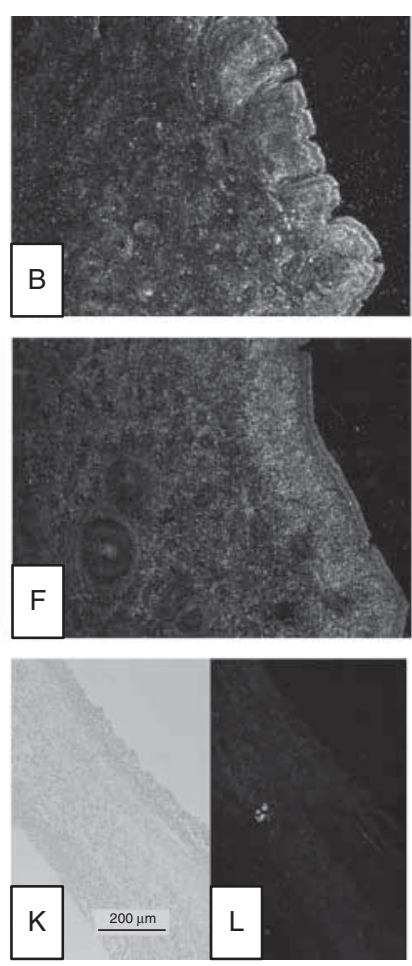

Figure 3

Bright field ( $A, C, E, G, I, K$, and $M$ ) or dark field images ( $B, D, F, H, J, L$, and $N$ ) of INHBA mRNA expression in uterine tissue collected from control Romney ewes on days $14(A, B, C$, and $D), 16(E, F, G$, and $H)$ or 18 (M and $N)$ of the oestrous cycle (A, B, E, and F) or pregnancy (C, D, G, H, M, and N). Control ovarian tissue was hybridised with either antisense (I, J; positive control) or sense ( $\mathrm{K}, \mathrm{L}$; negative control) INHBA RNA probes. Expression of INHBA mRNA was found to be expressed by the LE and stromal cells of the
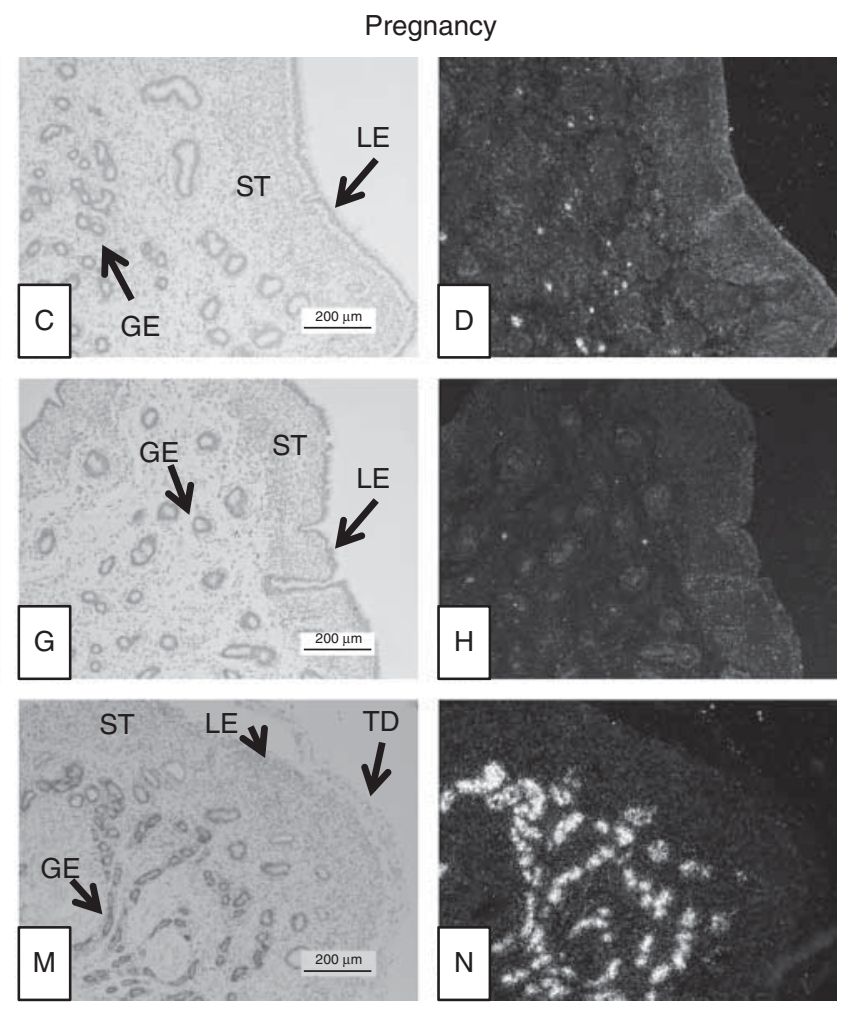

effects of activin A on progesterone production from luteinising granulosa cells. Concentrations of progesterone in media collected from days 4-6 of culture from ovine granulosa cells treated with activin A were decreased $(P<0.001)$ to $7.4 \pm 1.5 \%$ of that observed in control cells. Treatment with activin A did not affect $(P<0.15)$ the amount of DNA measured at the end of culture (activin A treated cells had $70.1 \pm 17.3 \%$ of the DNA measured in control cells).

\section{Discussion}

In the present study, a modest increase of activin A was observed in plasma with a larger increase in uterine fluid in ewes with reduced ES compared to those with enhanced ES. No such variations in concentrations of FST were detected indicative of an increased activin tone. The mechanisms by which increases in activin might cause reproductive failure endometrium compactum in uterine tissue collected during the oestrous cycle. In pregnant uterine tissue, INHBA expression was also observed in the glandular epithelia on day 14 of gestation with distinct expression at day 18 of gestation. Expression was observed in the granulosa cells of the ovarian follicle when hybridised with the anti-sense RNA (I, J; positive control) but not with the sense RNA (K, L; negative control).

are unclear. A delicate balance between the pro- and antiinflammatory environment is mediated through cytokine and chemokine signalling with significant variation among species (van Mourik et al. 2009). It is possible that overexpression of activin leads to disruption of this delicate balance resulting in rejection of the developing conceptus. Activin A has also been shown to stimulate proliferation of bovine endometrial cells (Sugawara et al. 2010). Alternatively, if activin concentrations are altered in the preovulatory follicle, this could potentially affect oocyte quality or subsequent luteal function. Increased expression of FST by the oocyte has also been linked to enhanced oocyte quality as assessed by improved early embryo development (Rajput et al. 2013). However, it should be noted that it is unclear if the positive effects of FST on oocyte quality and embryo development are due to neutralisation of activin as treatment with activin A mimicked FST actions, albeit with less potency (Rajput et al. 2013).

Published by Bioscientifica Ltd 

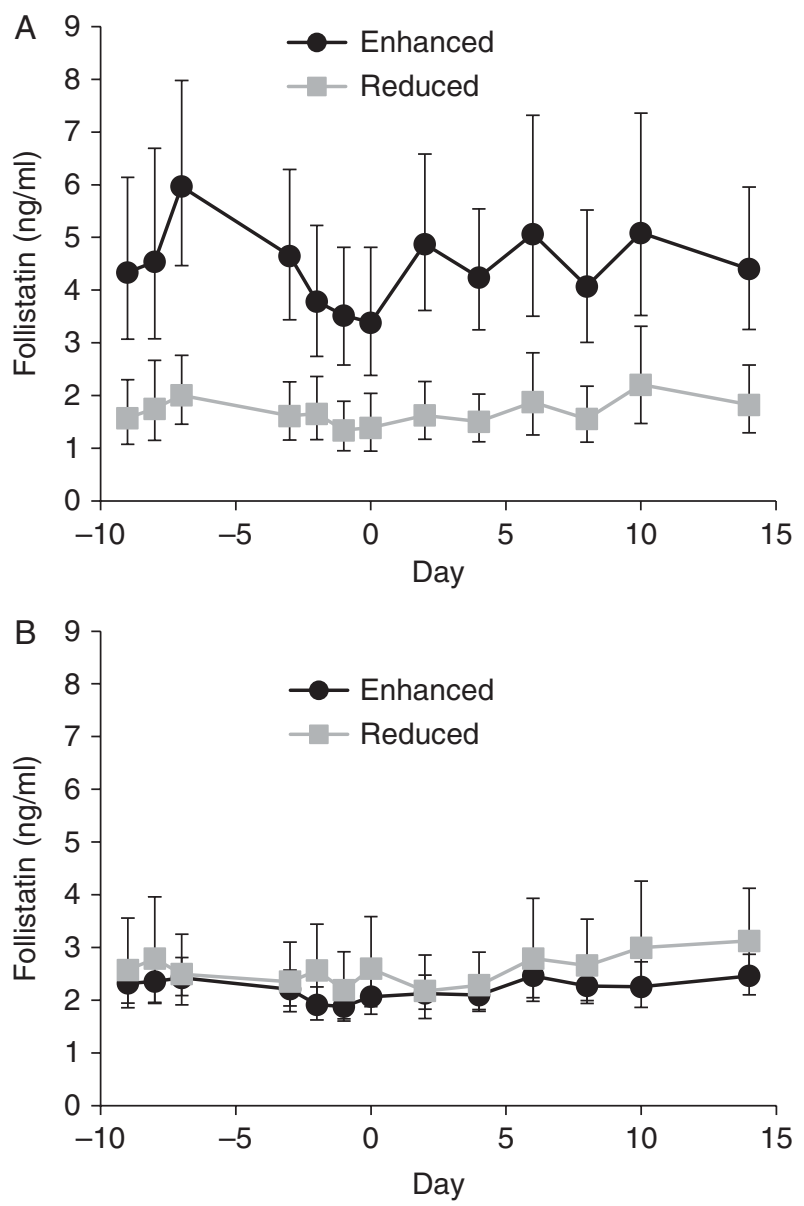

Figure 4

Concentrations (geometric means and $95 \%$ confidence limits) of FST in plasma from ewes with enhanced or reduced ES across the cycle. Data collected from non-pregnant ewes are shown in panel A ( $n=5$ and $n=4$ for enhanced and reduced ES respectively) whereas data collected from pregnant ewes are shown in panel B ( $n=14$ and $n=8$ for enhanced and reduced ES respectively). Day 0 equals the day of oestrus/breeding.

A key pathway that may be affected by increased activin secretion is luteinisation of the granulosa cells and subsequent luteal function. Concentrations of activin A in the peripheral circulation were low during most of the cycle, but a peak of activin A occurred around oestrus. The preovulatory follicle strongly expresses INHBA mRNA (Engelhardt et al. 1993, Tisdall et al. 1994), and this peak could be driven by growth of the preovulatory follicle. However, concentrations of activin A were not higher in follicular fluid of oestrogen-active follicles than oestrogeninactive follicles (Young et al. 2012); so, the source of the peak of activin A observed around oestrous needs to be confirmed.

We have previously shown that these ewes with enhanced ES have increased concentrations of progesterone both in the systemic as well as the uterine circulations, potentially linked to improved function of the corpus luteum (O'Connell et al. 2013). In the current study, we have shown that treatment of luteinising ovine granulosa cells with activin A reduced progesterone secretion; thus, the increased activin A concentrations observed around the time of oestrous in the reduced ES ewes may have resulted in poor luteal function in these ewes. Similar to what was observed in the current study, activin A has been shown to reduce luteinisation of granulosa cells in vitro in both humans and cattle (Myers et al. 2008, Kayani et al. 2009). Activin A also suppressed progesterone production in vitro from granulosa cells collected from preovulatory follicles in rats (Miro et al. 1991).

An increase in activin concentrations has been found to be associated with reproductive failure in women (Rombauts et al. 2006). Elevated activin concentrations have been linked to reduced adhesion of the blastocyst to the LE (Stoikos et al. 2008). However, others have found higher concentrations of activin $\mathrm{A}$ in uterine fluid collected during the periovulatory period in women who became pregnant after intrauterine insemination compared to those that failed to establish a pregnancy (Florio et al. 2010). Moreover, using semi-quantitative immunohistochemical techniques, Prakash et al. (2006) observed reduced staining for both activin A and FST in women with recurring miscarriages. The differences between these studies could be related to differing days

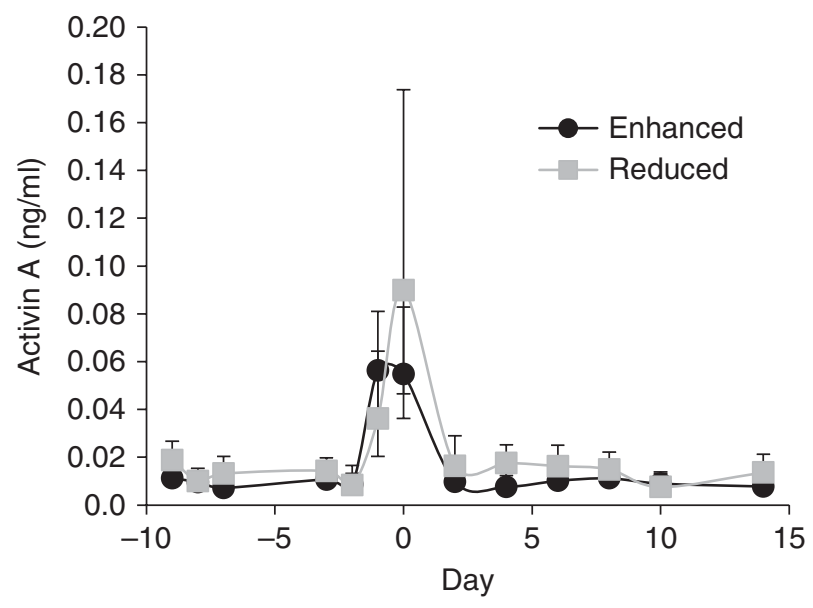

Figure 5

Concentrations (geometric means and $95 \%$ confidence limits) of activin A in plasma from ewes with enhanced $(n=19)$ or reduced $(n=12)$ ES across the cycle. Data collected during the oestrous cycle and early gestation were combined, as there were no group by pregnancy status interactions. Day 0 equals the day of oestrus.

Published by Bioscientifica Ltd. 
Table 2 Relative expression of FST and activin A expression in uterine flush media collected on day 16 of gestation from ewes with enhanced or reduced ES

\begin{tabular}{|c|c|c|c|c|}
\hline $\begin{array}{l}\text { Protein } \\
(\mathrm{ng} / \mathrm{ml})\end{array}$ & $\begin{array}{l}\text { Enhanced } \\
\text { ES }(n=14)\end{array}$ & $\begin{array}{l}\text { Reduced ES } \\
\quad(n=7)\end{array}$ & SED & $P$ value \\
\hline activin $\mathrm{A}$ & 0.45 & 1.05 & 0.24 & 0.022 \\
\hline FST & 105.2 & 121.8 & 19.8 & 0.412 \\
\hline
\end{tabular}

of sample collection or methods of measuring activin and FST, but may also signify the requirement for a balance of activin activity, with under or overexpression being detrimental to pregnancy outcome.

The observed differences in concentrations of activin A were found locally in uterine fluid. The uterus could be synthesising activin A, as mRNA encoding INHBA, which dimerises to form activin $\mathrm{A}$, is expressed by the uterus. Average concentrations of INHBA mRNA in endometrium of reduced ES ewes were $167 \%$ of that observed in enhanced ES ewes, which is consistent with a twofold increase observed in concentrations of activin A in uterine fluid. However, this difference did not reach significance, potentially because concentrations of INHBA mRNA were quite variable between animals. This variability could be due to heterogeneity of cell types within the endometrial sample collected (Bauersachs 2014). Expression of INHBA mRNA was detected in uterine LE of both day 14 nonpregnant and pregnant ewes, but expression was limited to the glandular epithelium in day 18 pregnant ewes. Expression of INHBA has previously been observed in the developing ovine uterus (prior to puberty) with strongest expression in the luminal and glandular epithelia (Hayashi et al. 2003). Altered uterine gland development was induced by ovariectomy and linked to reduced expression of INHBA mRNA and protein (Carpenter et al. 2003). Taken together, these studies support a role for activin A in regulation of uterine function in sheep throughout the lifetime of a ewe.

There was some evidence that plasma concentrations of FST were greater in ewes with enhanced ES, as combined analysis of samples collected in pregnant and nonpregnant sheep revealed increased plasma FST concentrations in ewes with enhanced ES. However, this increased plasma FST was driven by differences observed in the first year, when the ewes were not exposed to a fertile ram, with no differences observed in the second year, when the ewes were exposed to a fertile ram and thus became pregnant during the blood collection period. Given that some of the samples collected from the pregnant sheep were taken before exposure to the fertile ram, and thus these samples would be physiologically equivalent to those samples collected from the nonpregnant sheep, the failure to observe differences in both groups of sheep indicates that the increased concentration of plasma FST is not consistently observed but may represent a differing response of enhanced and reduced ES ewes to environmental conditions. These environmental conditions are unknown at this time, and a better understanding of how environmental factors may regulate FST concentrations may provide new insights into variability in ES. No differences in FST concentrations were observed in uterine fluid nor were any differences observed in expression of FST mRNA in the endometrium. However, it is clear that increased concentrations of activin in the low ES ewes were not accompanied by an increase in neutralising FST.

The mRNA encoding FST was expressed primarily in the LE with expression also observed in the trophectoderm of the developing conceptus. The expression of FST mRNA has also been observed in developing ovine uterine tissue, although expression in the epithelial cells was observed shortly after birth, and expression was not detected in developing glandular epithelium between days 21 and 56 after birth (Hayashi et al. 2003). Thus, expression of FST mRNA appears to be regulated in the ovine uterus under differing reproductive states. In cattle, the non-gravid and gravid uterine horns, as well as foetal membranes, from day 35 of pregnancy, express FST mRNA (Sugawara et al. 2010). FST mRNA is also expressed in ovarian tissues, particularly the granulosa cells of ovarian follicles as well as other tissues (Tisdall et al. 1994). Circulating concentrations of FST were reduced around oestrus compared to the peak levels of activin A at that time being indicative of a higher activin tone around oestrus and ovulation. However, it should be noted that the decrease in FST observed in this study was relatively minor, with only a $20 \%$ difference between the nadir and peak values. Previous studies have shown that FST expression is unvarying throughout the oestrous cycle (McFarlane et al. 2002, Xia et al. 2010).

In summary, differences in activin A concentrations, both in the systemic circulation and in uterine fluid, were observed in ewes with differing lifetime ES phenotypes. Ewes with reduced ES had elevated concentrations of activin A, without concomitant changes in FST concentrations, indicative of an increase in activin tone. A peak of activin A was observed around oestrus, and activin A was shown to supress progesterone production by luteinising ovine granulosa cells in vitro; thus, the increased activin A

Published by Bioscientifica Ltd 
concentration may underlie the supressed progesterone concentrations observed during the early luteal phase in these animals (O'Connell et al. 2013). The expression of INHBA and FST mRNA in the uterus/conceptus, as well as increased activin A concentrations in uterine fluid of ewes with poor ES, is also consistent with a role for activin A in regulating local interactions between the conceptus and uterus during implantation.

\section{Declaration of interest}

The authors declare that there is no conflict of interest that could be perceived as prejudicing the impartiality of the research reported.

\section{Funding}

The research was supported by the New Zealand Ministry of Business, Innovation \& Employment (formerly Foundation for Research, Science \& Technology), New Zealand (grant number: C10X1001), and AgResearch Core Funding.

\section{Acknowledgements}

We thank Ms Susan Hayward and A/Prof. Mark Hedger at the Monash Institute of Medical Research, Monash University for performing the activin $A$ and FST assays. Provision of reagents for the activin A ELISA by Oxford Brookes University is gratefully acknowledged. We would also like to thank Michelle French for performing the quantitative PCR assays. We would also like to thank Laurel Quirke for her help with the in situ hybridisation technique and Dr Carey Satterfield and Dr David Phillips for insightful discussion on embryo survival and activin and FST. The help of members of the Animal Reproduction team and the Invermay farm staff for sample collection and animal care and management is also greatly appreciated.

\section{References}

Bauersachs S 2014 Combined analysis of transcriptome studies of bovine endometrium during the preimplantation phase and comparison to results obtained ovine and porcine preimplantation endometrium. In Reproduction in Domestic Ruminants VIII, pp 167-177. Eds JL Juengel, A Miyamoto, C Price, LP Reynolds, MF Smith \& R Webb. Ashby de la Zouch, Leicestershire, UK: Context Products Ltd.

Carpenter KD, Hayashi K \& Spencer TE 2003 Ovarian regulation of endometrial gland morphogenesis and activin-follistatin system in the neonatal ovine uterus. Biology of Reproduction 69 851-860. (doi:10.1095/biolreprod.103.016337)

Diskin MG \& Morris DG 2008 Embryonic and early foetal losses in cattle and other ruminants. Reproduction in Domestic Animals 43(Suppl 2) 260-267. (doi:10.1111/j.1439-0531.2008.01171.x)

Engelhardt H, Smith KB, McNeilly AS \& Baird DT 1993 Expression of messenger ribonucleic acid for inhibin subunits and ovarian secretion of inhibin and estradiol at various stages of the sheep estrous cycle. Biology of Reproduction 49 281-294. (doi:10.1095/ biolreprod49.2.281)

Florio P, Bruni L, Galleri L, Reis FM, Borges LE, Bocchi C, Litta P, De Leo V \& Petraglia F 2010 Evaluation of endometrial activin A secretion for prediction of pregnancy after intrauterine insemination. Fertility and Sterility 93 2316-2320. (doi:10.1016/j.fertnstert.2008.12.125)
Gleit A 1985 Estimation for small normal data sets with detection limits. Environmental Science \& Technology 19 1201-1206. (doi:10.1021/ es00142a011)

Hanrahan JP 1982 Selection for increased ovulation rate, litter size and embryo survival. In 2nd World Congress on Genetics Applied to Livestock Production, volume 5, pp 294-309. Madrid, Spain: Editorial Garsi.

Hayashi K, Carpenter K, Gray CA \& Spencer TE 2003 The Activin-Follistatin system in the neonatal ovine uterus. Biology of Reproduction 69 843-850. (doi:10.1095/biolreprod.103.016287)

Juengel JL, Bibby AH, Reader KL, Lun S, Quirke LD, Haydon LJ \& McNatty KP 2004 The role of transforming growth factor- $\beta$ (TGF- $\beta$ ) during ovarian follicular development in sheep. Reproductive Biology and Endocrinology 2 78. (doi:10.1186/1477-7827-2-78)

Kayani AR, Glister C \& Knight PG 2009 Evidence for an inhibitory role of bone morphogenetic protein(s) in the follicular-luteal transition in cattle. Reproduction 137 67-78. (doi:10.1530/REP-08-0198)

Kelly RW \& Allison AJ 1976 Measurement of ovulation rate by laparoscopy and effects on reproductive performance. Proceedings of the New Zealand Society of Animal Production 36 240-246.

Knight PG 1996 Roles of inhibins, activins, and follistatin in the female reproductive system. Frontiers in Neuroendocrinology 17 476-509. (doi:10.1006/frne.1996.0013)

Knight PG, Muttukrishna S \& Groome NP 1996 Development and application of a two-site enzyme immunoassay for the determination of 'total' activin-A concentrations in serum and follicular fluid. Journal of Endocrinology 148 267-279. (doi:10.1677/joe.0.1480267)

Knight PG, Satchell L \& Glister C 2012 Intra-ovarian roles of activins and inhibins. Molecular and Cellular Endocrinology 359 53-65. (doi:10.1016/ j.mce.2011.04.024)

Logan KA, Juengel JL \& McNatty KP 2002 Onset of steroidogenic enzyme gene expression during ovarian follicular development in sheep. Biology of Reproduction 66 906-916. (doi:10.1095/biolreprod66.4.906)

Lun S, Smith P, Lundy T, O'Connell A, Hudson N \& McNatty KP 1998 Steroid contents of and steroidogenesis in vitro by the developing gonad and mesonephros around sexual differentiation in fetal sheep. Journal of Reproduction and Fertility 114 131-139. (doi:10.1530/jrf.0.1140131)

McFarlane JR, Xia Y, O'Shea T, Hayward S, O'Connor AE \& De Kretser DM 2002 Follistatin concentrations in maternal and fetal fluids during the oestrous cycle, gestation and parturition in Merino sheep. Reproduction 124 259-265. (doi:10.1530/rep.0.1240259)

Mellor SL, Ball EM, O'Connor AE, Ethier JF, Cranfield M, Schmitt JF, Phillips DJ, Groome NP \& Risbridger GP 2003 Activin betaC-subunit heterodimers provide a new mechanism of regulating activin levels in the prostate. Endocrinology 144 4410-4419. (doi:10.1210/ en.2003-0225)

Miro F, Smyth CD \& Hillier SG 1991 Development-related effects of recombinant activin on steroid synthesis in rat granulosa cells. Endocrinology 129 3388-3394. (doi:10.1210/endo-129-6-3388)

van Mourik MSM, Macklon NS \& Heijnen CJ 2009 Embryonic implantation: cytokines, adhesion molecules, and immune cells in establishing an implantation environment. Journal of Leukocyte Biology 85 4-19. (doi:10.1189/jlb.0708395)

Myers M, van den Driesche S, McNeilly AS \& Duncan WC 2008 Activin A reduces luteinisation of human luteinised granulosa cells and has opposing effects to human chorionic gonadotropin in vitro. Journal of Endocrinology 199 201-212. (doi:10.1677/JOE-08-0302)

O'Connell AR, Hurst PR, Davis GH, McNatty KP, Taylor SL \& Juengel JL 2013 An earlier rise in systemic progesterone and increased progesterone in the uterine vein during early pregnancy are associated with enhanced embryonic survival in the ewe. Theriogenology $\mathbf{8 0}$ 269-274. (doi:10.1016/j.theriogenology.2013.04.006)

Parr RA 1992 Nutrition-progesterone interactions during early pregnancy in sheep. Reproduction, Fertility, and Development 4 297-300. (doi:10.1071/RD9920297)

Phillips DJ, Hedger MP, McFarlane JR, Klein R, Clarke IJ, Tilbrook AJ, Nash AD \& de Kretser DM 1996 Follistatin concentrations in male 
sheep increase following sham castration/castration or injection of interleukin-1 $\beta$. Journal of Endocrinology 151 119-124. (doi:10.1677/joe. $0.1510119)$

Prakash A, Li TC, Tuckerman E, Laird S, Wells M \& Ledger WL 2006 A study of luteal phase expression of inhibin, activin, and follistatin subunits in the endometrium of women with recurrent miscarriage. Fertility and Sterility 86 1723-1730. (doi:10.1016/j.fertnstert.2006.05.040)

Quinlivan TD, Martin CA, Taylor WB \& Cairney IM 1966 Estimates of pre- and perinatal mortality in the New Zealand Romney Marsh ewe. I. Pre- and perinatal mortality in those ewes that conceived to one service. Journal of Reproduction and Fertility 11 379-390. (doi:10.1530/jrf.0. 0110379)

Rajput SK, Lee K, Zhenhua G, Di L, Folger JK \& Smith GW 2013 Embryotropic actions of follistatin: paracrine and autocrine mediators of oocyte competence and embryo developmental progression. Reproduction, Fertility, and Development 26 37-47. (doi:10.1071/ RD13282)

Robinson RS, Hammond AJ, Wathes DC, Hunter MG \& Mann GE 2008 Corpus luteum-endometrium-embryo interactions in the dairy cow: underlying mechanisms and clinical relevance. Reproduction in Domestic Animals 43(Suppl 2) 104-112. (doi:10.1111/j.1439-0531.2008.01149.x)

Rombauts L, Donoghue J, Cann L, Jones RL \& Healy DL 2006 Activin-A secretion is increased in the eutopic endometrium from women with endometriosis. Australian \& New Zealand Journal of Obstetrics \& Gynaecology 46 148-153. (doi:10.1111/j.1479-828X.2006.00546.x)

Shorten PR, Peterson AJ, O'Connell AR, Juengel JL, McNatty KP \& Soboleva TK 2010 A mathematical model of pregnancy recognition in mammals. Journal of Theoretical Biology 266 62-69. (doi:10.1016/ j.jtbi.2010.06.005)

Shorten PR, O'Connell AR, Demmers KJ, Edwards SJ, Cullen NG \& Juengel JL 2013 Effect of age, weight, and sire on embryo and fetal survival in sheep. Journal of Animal Science 91 4641-4653. (doi:10.2527/ jas.2013-6415)
Singh M, Chaudhry P \& Asselin E 2011 Bridging endometrial receptivity and implantation: network of hormones, cytokines, and growth factors. Journal of Endocrinology 210 5-14. (doi:10.1530/JOE-10-0461)

Spencer TE, Johnson GA, Bazer FW \& Burghardt RC 2004 Implantation mechanisms: insights from the sheep. Reproduction 128 657-668. (doi:10.1530/rep.1.00398)

Stoikos CJ, Harrison CA, Salamonsen LA \& Dimitriadis E 2008 A distinct cohort of the TGF $\beta$ superfamily members expressed in human endometrium regulate decidualization. Human Reproduction $\mathbf{2 3}$ 1447-1456. (doi:10.1093/humrep/den110)

Sugawara K, Kizaki K, Herath CB, Hasegawa Y \& Hashizume K 2010 Transforming growth factor $\beta$ family expression at the bovine feto-maternal interface. Reproductive Biology and Endocrinology 8120. (doi:10.1186/1477-7827-8-120)

Tisdall DJ, Hudson N, Smith P \& McNatty KP 1994 Localization of ovine follistatin and $\alpha$ and $\beta$ A inhibin mRNA in the sheep ovary during the oestrous cycle. Journal of Molecular Endocrinology 12 181-193. (doi:10.1677/jme.0.0120181)

Walton KL, Makanji Y \& Harrison CA 2012 New insights into the mechanisms of activin action and inhibition. Molecular and Cellular Endocrinology 359 2-12. (doi:10.1016/j.mce.2011.06.030)

Wilmut I, Sales DI \& Ashworth CJ 1985 Physiological criteria for embryo mortality: is asynchrony between embryo and ewe a significant factor? In Genetics of Reproduction in Sheep, pp 275-289. Eds RB Land \& DW Robinson. London, UK: Butterworths.

Xia Y, O'Shea T, Almahbobi G \& McFarlane JR 2010 Changes in ovarian follistatin levels during the oestrous cycle in sheep may serve as an intraovarian regulator. Reproduction in Domestic Animals 45 509-515. (doi:10.1111/j.1439-0531.2008.01283.x)

Young JM, Henderson S, Souza C, Ludlow H, Groome N \& McNeilly AS 2012 Activin B is produced early in antral follicular development and suppresses thecal androgen production. Reproduction 143 637-650. (doi:10.1530/REP-11-0327)

Received in final form 13 December 2015

Accepted 24 December 2015

Accepted Preprint published online 5 January 2016
(C) 2016 Society for Endocrinology Printed in Great Britain 